\title{
Sugarbeet Fertilization with Three (Sugarbeet) Vinasse Composts
}

\author{
MADEJÓN, E.*, DÍAZ, M.J.**, LÓPEZ, R.**, \\ MURULLO, J.M.** and CABRERA, F.**
}

The recycling of the organic wastes from different industries could satisfy the increasing demand for organic materials in agriculture and horticulture.

Beet molasses are used as raw material for production of alcohol by distillation. For each litre of alcohol, nearly fifteen litres of a dark brown effluent known as vinasse are generated. The high salt content of the vinasse produced in the south of Spain limits its use for animal feeding. Therefore the use of this waste as fertilizer is being studied at present (López et al., 1993). Vinasse has three major problems for direct application as fertilizer: (i) high salt content (EC 250-300 dS m21), (ii) low $\mathrm{P}$ content $\left(\mathrm{P}_{2} \mathrm{O}_{5} 0.012 \%\right)$ and (iii) its liquid dense character $(1.3 \mathrm{~g} \mathrm{~cm} 23)$. These problems may be overcome through the co-composting of vinasse with agricultural solid wastes, thus obtaining a compost which can be used as fertilizer.

In this paper, the effect of deep fertilization with three vinasse composts as an altemative to traditional mineral fertilizer on sugarbeet is considered. Nutritional status, yield and quality of sugarbeet cultivated in a sandy loam soil fertilized with three vinasse composts and a mineral fertilizer were compared.

Three mixtures of vinasse and agricultural solid wastes were co-composted in static piles with forced aeration during four months. The initial proportion of solid wastes and vinasse were: Compost G: grape marc (82\%) + sugarbeet factory lime $(1 \%)+$ vinasse $(17 \%)$; Compost $\mathrm{O}$ : olive pressed cake $(76 \%)+$ sugarbeet factory lime $(1 \%)+$ leonardite $(6 \%)+$ vinasse $(17 \%)$; Compost $\mathrm{C}$ : cotton gin trash $(47 \%)+$ sugarbeet factory lime $(1 \%)+$ leonardite $(3 \%)+$ vinasse $(49 \%)$. The chemical analysis of the three composts is shown in Table 1.

Some relevant characteristics of the soil at two different depths (20 and $40 \mathrm{~cm}$ ) are given in Table 2. Field experiments were carried out in duplicated plots of 10 $\times 15 \mathrm{~m}$, in which five treatments were tested. Each plot were subdivided in four subplots from where plants and roots samples were taken.The following doses for treatments were applied: TG $14,000 \mathrm{~kg} \mathrm{ha}^{-1}$ of G; TO $22,000 \mathrm{~kg} \mathrm{ha}^{-1}$ of O, TC $15,000 \mathrm{~kg} \mathrm{ha}^{-1}$ of C; TF $600 \mathrm{~kg} \mathrm{ha}^{-1}$ of a 9-18-27 N-P-K mineral fertilizer. Treatments TO and TC were complemented with 158 and $122 \mathrm{~kg} \mathrm{ha}^{-1}$ of $\mathrm{P}_{2} \mathrm{O}$ as superphosphate, respectively. A treatment, TB, without fertilization was used as control. All treatments, except TB, received two top dressings of urea $(46 \% \mathrm{~N})$,

EBRO AGRICOLAS S.A. Apdo. 9,41300 S. Jose de la Rinconada, Sevilla, Spain. Instituto de Recursos Naturales y Agrobiología de Sedlla (CSIC). Apdo. 1052, 41080 Sevilla, Spain. 
equivalent to $2 \times 90 \mathrm{~kg} \mathrm{ha}^{-1}$. Sugarbeet c.v. Taurus was the test variety used fol the experiment. Plant material was collected at 33 and 164 days after sowing. Mineral elements in leaves were analyzed acording to Jones et al., (1990). The data were analyzed by ANOVA and the differences between treatments were compared by Tukey's test.

Table 1 Chemical composition of the compost (Oven-dry basis)

\begin{tabular}{ccccc}
\hline COMPOST & & G & O & C \\
\hline Moisture & $\%$ & 31 & 25 & 18 \\
N-Kjeldahl & $\%$ & 2.10 & 1.00 & 2.60 \\
Plo5 & $\%$ & 0.70 & 0.13 & 0.28 \\
K20 & $\%$ & 1.30 & 0.90 & 2.10 \\
OM & $\%$ & 50 & 70 & 51 \\
$\mathrm{Ha}$ & $\%$ & 1.70 & 1.30 & 2.40 \\
$\mathrm{Ca}$ & $\%$ & 2.80 & 1.90 & 1.30 \\
$\mathrm{Mg}$ & $\%$ & 0.30 & 0.20 & 0.40 \\
$\mathrm{C} N$ & $\%$ & 12 & 34 & 8.2 \\
\hline
\end{tabular}

The nutrients contents in leaves at 33 days after the sowing did not differ significantly among treatments (data not shown). The $\mathrm{N}, \mathrm{P}, \mathrm{K}, \mathrm{Ca}, \mathrm{Mg}$ and $\mathrm{Ha}$ contents in leaves at 164 days after the sowing are shown in Table 3 . The nutrient contents in composts and mineral fertilizer treatments were higher than for TB treatment. For the compost treatments, the sodium contents were similar to that of the mineral treatment, despite the high $\mathrm{Ha}$ contents of the composts. Nutrient contents were within the usual ranges reported for similar climate conditions (Cantos, 1988).

Table 2 Analytical characteristics of the soil

\begin{tabular}{|c|c|c|c|}
\hline & & \multicolumn{2}{|c|}{ DEPTH $(\mathrm{cm})$} \\
\hline PARAMETERS & & $0-20$ & $20-40$ \\
\hline Sand & $(\%)$ & 79.4 & 81.3 \\
\hline Silt & (\%) & 10.6 & 9.7 \\
\hline Clay & (\%) & 10 & 9 \\
\hline $\mathrm{pH}\left(\mathrm{H}_{2} \mathrm{O}\right)$ & & 8.1 & 8.2 \\
\hline $\mathrm{CaCO}_{3}$ & (\%) & 8.8 & 7.2 \\
\hline $\mathrm{OM}^{3}$ & (\%) & 0.8 & \\
\hline Kjeldahi-N & $\mathrm{mg} \mathrm{kg}{ }^{-1}$ & 676 & 675 \\
\hline Available-P & $\mathrm{mg} \mathrm{kg} \mathrm{kg}^{-1}$ & 16 & \\
\hline Available-K & $\mathrm{mg} \mathrm{kg}^{-1}$ & 175 & 205 \\
\hline
\end{tabular}

Sugarbeet root yields for all treatments are shown in Figure 1. There was an apparent treatment effect on sugarbeet root yield. Plots fertilized with either of the composts or the mineral fertilizer gave significantly higher yields than plots without fertilization. For treatments TG, TC and TF, sugarbeet root yields were threefold higher than for treatment TB, while the sugarbeet root for treatments TO was only two-fold higher than for treatment TB. No significant differences on sugarbeet root yield were observed between each of the three compost treatments and 
the mineral fertilizer treatment. The production of sugar followed the same pattern, where the highest sugar production was obtained for treatment TG (Figure 1).

Parameters indicating the quality of sugarbeet juice for sugar production were determined following the standard methods of the British Sugar Company (Table 4).

Table 3 Nutritional content in the ear leaf at 164 days afrer the sowing

\begin{tabular}{ccccccc}
\hline TREATMENTS & $\begin{array}{c}\mathrm{N} \\
\%\end{array}$ & $\begin{array}{c}\mathrm{P} \\
\%\end{array}$ & $\begin{array}{c}\mathrm{K} \\
\%\end{array}$ & $\begin{array}{c}\mathrm{Ha} \\
\%\end{array}$ & $\begin{array}{c}\mathrm{Ca} \\
\%\end{array}$ & $\begin{array}{c}\mathrm{Mg} \\
\%\end{array}$ \\
\hline TB & $3.93 \mathrm{a}$ & $0.33 \mathrm{a}$ & $3.30 \mathrm{a}$ & $281 \mathrm{a}$ & $1.11 \mathrm{a}$ & $0.90 \mathrm{a}$ \\
TG & $4.83 \mathrm{c}$ & $0.41 \mathrm{c}$ & $4.34 \mathrm{c}$ & $3.68 \mathrm{~b}$ & $1.28 \mathrm{a}$ & $1.41 \mathrm{c}$ \\
TO & $4.60 \mathrm{bc}$ & $0.37 \mathrm{ab}$ & $4.53 \mathrm{ab}$ & $4.37 \mathrm{c}$ & $1.13 \mathrm{a}$ & $1.08 \mathrm{~b}$ \\
TC & $4.88 \mathrm{c}$ & $0.40 \mathrm{bc}$ & $3.94 \mathrm{bc}$ & $4.32 \mathrm{c}$ & $1.03 \mathrm{a}$ & $1.33 \mathrm{c}$ \\
TF & $4.53 \mathrm{bc}$ & $0.38 \mathrm{bc}$ & $4.09 \mathrm{bc}$ & $4.08 \mathrm{c}$ & $1.11 \mathrm{a}$ & $1.18 \mathrm{~b}$ \\
\hline
\end{tabular}

Values following by the same letter in the sane column do not differ significantly $(P<0.05)$.

Table 4 Sugarbeet quality

\begin{tabular}{cccccc}
\hline TREATMENTS & $\begin{array}{c}\text { Red. suga } \\
\%\end{array}$ & $\begin{array}{c}\text { Sugar } \\
\%\end{array}$ & $\begin{array}{c}\mathrm{Na} \\
\text { meq/l00g }\end{array}$ & $\begin{array}{c}\mathrm{K} \\
\text { meq/100g }\end{array}$ & $\begin{array}{c}\alpha \text {-aminoacid } \\
\text { meq/100g }\end{array}$ \\
\hline TB & $0.17 \mathrm{a}$ & $15.9 \mathrm{a}$ & $2.67 \mathrm{a}$ & $5.71 \mathrm{a}$ & $0.55 \mathrm{a}$ \\
TG & $0.15 \mathrm{a}$ & $15.8 \mathrm{a}$ & $3.07 \mathrm{a}$ & $6.41 \mathrm{bc}$ & $1.45 \mathrm{ab}$ \\
TO & $0.18 \mathrm{a}$ & $16.3 \mathrm{a}$ & $271 \mathrm{a}$ & $5.79 \mathrm{ab}$ & $1.30 \mathrm{ab}$ \\
TC & $0.16 \mathrm{a}$ & $16.6 \mathrm{a}$ & $3.01 \mathrm{a}$ & $7.01 \mathrm{c}$ & $2.01 \mathrm{~b}$ \\
TF & $0.14 \mathrm{a}$ & $16.6 \mathrm{a}$ & $3.50 \mathrm{a}$ & $6.60 \mathrm{c}$ & $2.06 \mathrm{~b}$ \\
\hline
\end{tabular}

Values following by the sane letter in the sane column do not differ significantly $(P<0.05)$.

* Reducing sugar.

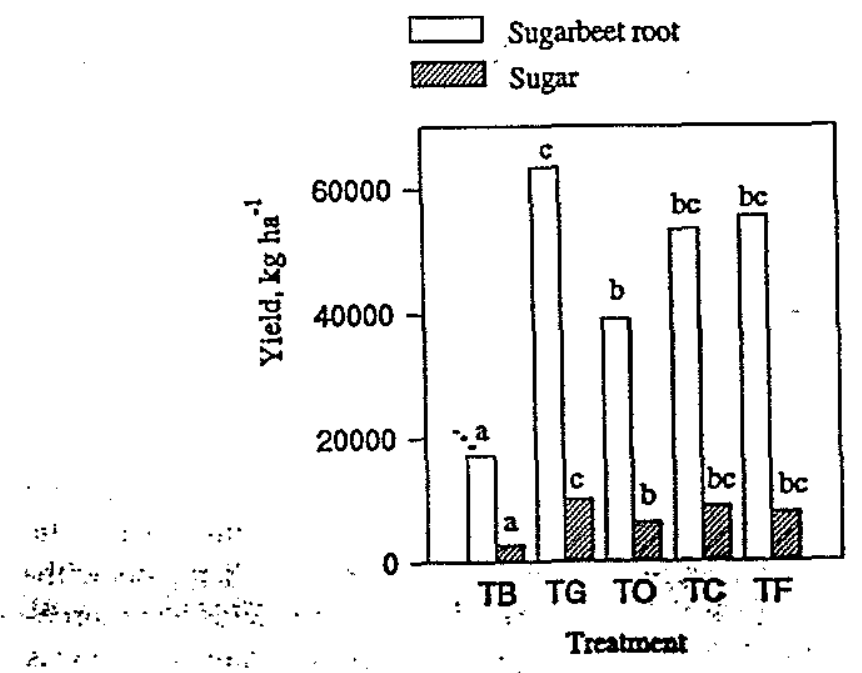

$\therefore$. Figure 1. Yield of sugabeet root and sugar for the different treatments. Means of data columns for cach yield with same letters are not significantly different $(P, 0.05)$. 
There were not significant differences among treatment on the percentage of reducing sugar, sugar and Ha contents in beet root. For treatments TG, TC and $\mathrm{TF}$, the $\mathrm{K}$ contents were significantly higher than for $\mathrm{TB}$.

The negative influence that high $\mathrm{N}$ fertilization may produce on the technological sugarbeet quality (Draycott, et al., 1977) was not apparent since the aaminoacid contents for composts and mineral fertilizer treatments were lower than the normal value $(6.4 \mathrm{meq} / \mathrm{l} 00 \mathrm{~g})$ for sugarbeet under similar climate conditions (Cantos, 1988).

Results highlighted the use of compost as an alternative of traditional mineral fertilizer. Compost of vinasse and agroindustrial wastes had not detrimental effects on sugarbeet (yield, nutritional status and quality). Best results were observed for vinasse-grape marc compost (G).

\section{References}

Cantos, M. (1988). Calidad tecnológica de la remolacha azucarera de siembra otoñal en la zona sur de Andalucía Occidental. Ph. D. University of Cordoba, Spain.

Draycott, A.P., Durrant, M.J. and Last, P.J. (1974). Effect of fertilizers on sugar beet quality. Int. Sugar J. $76,355-358$.

Jones, J.B.Jr., Eck, H.V. y Voss, R. (1990). Plant analysis as an aid in fertilizing sugarbeet. In Westermen, R.L. (ed.) 'Soil testing and plant analysis'. Chap. 16 Madison, SSSA.

López, R., Cabrera, F. y Murillo, J.M. (1993). Effect of beet vinasse on radish seeding emergence and fresh weight production. Acta Horticulture 335, 115-119. 